\title{
GEOENVIRONMENTAL IMPACT STUDIES FOR HYDRO-ENERGY PROJECTS: NARYN RIVER IN KYRGYZSTAN
}

\author{
TATYGUL URMAMBETOVA ${ }^{1,2}$, A. CHYMYROV²
}

\begin{abstract}
Geoenvironmental Impact Studies for Hydro-Energy Projects: Naryn River in Kyrgyzstan. Kyrgyzstan is the only country in Central Asia where water resources are fully formed in its own territory; these are its hydrological features and benefits. The country has considerable water and hydropower resources on its territory. There are over 25 thousand rivers and streams flowing from the mountains to the surrounding valleys carrying more than 50 cubic km annual water volume. The mountain rivers have a huge potential of water and hydro energy resources allowing Kyrgyzstan to reduce the traditional energy consumption. The hydro-energy projects enforces the socio-economic development of regions to meet the needs in the water, energy, flood control, etc., on the other hand they have a negative impact on the environment. Intensification of landslides, reservoir-induced seismicity, rise of groundwater level and land erosion and other environmental hazards need detailed investigations before, during construction and exploitation of hydropower stations. The geoinformation systems (GIS) and remote sensing technologies are recommended in the geoenvironmental impact studies of hydro-energy projects in the Naryn river basin. The efficiency in the use of integrated information systems created by combining the capabilities of GIS and remotely sensed data confirmed by numerous examples of successful use in practice, e.g. in the modeling of technical, natural and climate parameters to avoid disasters.
\end{abstract}

Keywords: water resources, hydroelectric potential, hydro-power plant, Naryn River, geoenvironmental impact.

\section{INTRODUCTION}

The water resources of Kyrgyzstan are one of the main national wealth which play an important role in human life, in the formation of flora and fauna, in the development of productive forces not only for the country but also a number

1 "Babeş-Bolyai" University, Faculty of Geography, 5-7 Clinicilor Street, Cluj-Napoca, Romania, e-mail: tatygul_urmambetova@yahoo.com.

${ }^{2}$ Kyrgyz State University of Construction, Transport and Architecture, Bishkek, Kyrgyzstan. 
of regions of Uzbekistan, Kazakhstan, Tajikistan and China. In Kyrgyzstan there are large rivers such as Naryn, Chu, Talas, Sary-Zhaz, Karadarya and others, which are flowing in the basins of Syr-Darya and Amu-Darya.

Natural resources significantly affect the socio - economic development of the state. Kyrgyzstan is a country in Central Asia, where hydropower resources are concentrated. At the present stage of economic development, sovereign Kyrgyzstan pays more attention to the study and rational use of water and hydropower resources. There is a strategy of the use of transboundary rivers, the method of pricing and rate for water in order to obtain compensatory reimbursement from the neighboring countries for the use of water resources and to solve the environmental problems (Kasymova et al., 2007).

\section{DATA AND MATERIALS}

Large glaciers and snow fields of mountain ranges are the source for many rivers, which are covering with a dense network the entire territory of the Kyrgyz Republic. These rivers originating in the high altitudes are characterized by a large slope, they are fast-flowing and have significant energy capabilities. Currently all over the world and also in the Kyrgyz Republic there is an interest in obtaining energy from renewable energy sources, which are the potential energy of the sun, water and biomass. The use of power plants that convert the energy of these sources in any other form of energy is aimed primarily in improving the supply of relatively small objects, located in areas remote from centralized electric and thermal networks, oil and gas pipelines.

On the territory of the Kyrgyz Republic there are dozens of large and hundreds of small rivers and canals which have thousands of mountain streams as tributaries. The estimated capacity of the hydropower potential of small water courses is 1.6 million $\mathrm{kW}$. The potential hydropower of small watercourses is expedient to direct to the small and micro hydro power plants, where the construction of centralized power lines is technically and economically not profitable.

The variations in amplitude of the working volume and energy consumption from year to year caused by the water discharge of the Naryn River results in the limited electricity production of the Naryn cascade power plants during the winter season. The highest energy consumption is between November and March. However, in this period the electricity generated by the Toktogul HPP (hydroelectric power plant) cascade is limited due to irrigation obligations of Kyrgyzstan to neighboring countries. Therefore, the electricity supply in the whole country and particularly in the Issyk-Kul region is insufficient. 
The rivers and streams of the Kyrgyz Republic are fed by melting water and the seasonal melt of snow and glaciers. The rainwater is negligible in the runoff of the rivers. Ground waters have a crucial importance for feeding the rivers during the cold season. The flood hydrograph data (water flow chart) on the rivers of the Kyrgyz Republic has a pectinate view. Two peaks are noticeable one in spring and another in summer.

\section{RESULTS AND DISCUSSIONS}

The studies of the Institute of Water Problems and Hydropower of the National Academy of Sciences of the Kyrgyz Republic have shown that the hydroelectric potential of small rivers of the Kyrgyz Republic in all its areas allows the construction of 92 new small hydropower plants with a total capacity about $178 \mathrm{MW}$ and an annual output up to $1.0 \mathrm{bln}$. KWh. In addition it would be possible to restore the pre-existing 39 small hydropower plants with a total capacity of $22 \mathrm{MW}$ and an annual output up to $100 \mathrm{mln}$. KWh. In the longer perspective, 7 HPP can be built on the irrigation reservoirs with an installed capacity of $75 \mathrm{MW}$ and an average annual power generation about 220 million KWh. This would significantly reduce the fuel supply dependence of remote and rural areas.

The following table shows the hydroelectric potential of small rivers of the Kyrgyz Republic (by regions) according to the research of the "Energy" KSTC (Kyrgyz scientific and technical center):

Table 1. The hydroelectric potential of small rivers of the Kyrgyz Republic (by regions)

\begin{tabular}{||l|c|c|c|}
\hline Regions & $\begin{array}{c}\text { Potential energy } \\
\text { capacity, thousand } \\
\text { kilowatt }\end{array}$ & $\begin{array}{c}\text { Potential energy, } \\
\text { million kilowatt- } \\
\text { hour }\end{array}$ & $\begin{array}{c}\text { Technically suitable for } \\
\text { development potential, } \\
\text { million kilowatt-hour }\end{array}$ \\
\hline \hline Chuy & 640 & 5545 & 500 \\
\hline Issyk-Kul & 2005 & 17390 & 1700 \\
\hline Talas & 354 & 3104 & 320 \\
\hline Naryn & 2032 & 1778 & 1600 \\
\hline Osh & 2641 & 2320 & 2300 \\
\hline Jalal-Abad & 1728 & 15045 & 1600 \\
\hline $\begin{array}{l}\text { Total million } \\
\text { kilowatt-hour }\end{array}$ & 9400 & 82072 & 8020 \\
\hline
\end{tabular}


Micro hydroelectric plants with $5 \mathrm{~kW}$ will provide electricity to the small farms which are remote from the settlements and centralized electric networks. The energy potential of micro and small hydroelectric plants depending on the magnitude of the water flow should be determined for the minimum flow in the cold season, as well as the nominal (on the required power) flow of the warm period of the year (Lepkin et al., 2007).

The biggest Kyrgyz hydroelectric plant is Toktogul hydroelectric station, which was set in operation in 1975. The lower Naryn cascade of hydropower plants have a total capacity of $2780 \mathrm{MW}$ including Toktogul reservoir (project capacity 19.5 billion cubic meters) of long-term operation and Kurpsai, Tashkumyr, Shamaldysai and Uchkurgan reservoirs with seasonal and daily regulation which also provide coverage of variable schedules load profiles of neighboring states and frequency regulation in the united energy systems of Central Asian (CA) region.

The optimal operation of the united energy systems of Central Asian region suggests providing mutual deliveries of electricity with the maximum production on the hydroelectric plant cascade during the vegetation season under the complex use of the hydropower resources of the Naryn-Syrdarya basin and the maximum production of thermal power plants in the autumnwinter period. For the region, the most important problem is the integrated use of the Toktogul waterworks in compliance with the interests of the lower countries - Kazakhstan and Uzbekistan and providing sanitary water releases to the Aral Sea basin (Kasymova et al., 2007).

The Kyrgyz energy system is part of the united energy systems of CA and operates in parallel mode with the energy systems of Uzbekistan, Kazakhstan and Tajikistan. The main plants are located in the South while $65 \%$ of the consumers live in the North of the country. The two regions are connected by a power line with the capacity $500 \mathrm{~kW}$ from the Toktogul HPP cascade to the substation of the Karabalta city area. The consumers of Kyrgyzstan experience an electricity deficit during autumn and winter and excess during the vegetation seasons. The electricity generated in the cascade of Toktogul hydroelectric power station enters the energy system of Uzbekistan and then through the Zhambyl region of Kazakhstan under the scheme of substitution to the north of Kyrgyzstan. In this way the power system of the Kyrgyz Republic works in parallel with the energy systems of Uzbekistan and Kazakhstan and is entirely dependent on neighboring countries for electricity transmission for its own consumption. The reason is the lack of connecting 500-220-110 kW networks (Kasymova et al., 2011). 


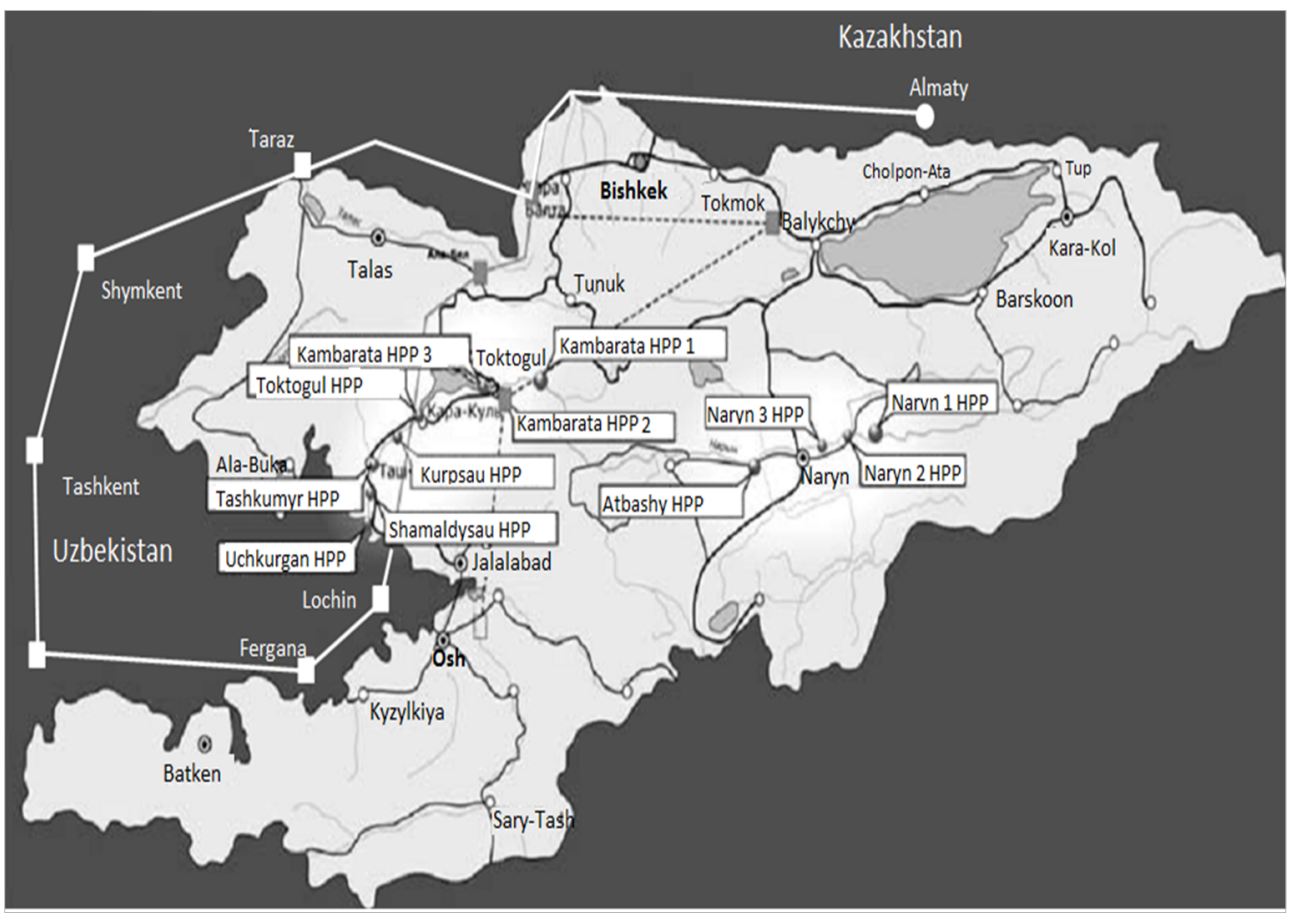

Fig. 1. The location scheme of the existing and perspective hydroelectric plants of the Kyrgyz Republic (source: Eurasian Economic Integration №3 (12))

The cyclic aridity in the Naryn river basin has resulted in a reduction of electricity generation of Toktogul HPP cascade and the particularly severe winter of 2007-2008 contributed to the multiple growths of loads by consumers, which has led to emergency blackouts due to wear and tear of equipment and electrical networks. The irregular distribution of energy facilities on the territory of the country is the reason for the deficit of capacity and electricity in the North of the country where many of the energy consumers are located. The Kyrgyz Republic takes second place in Central Asia in terms of the hydroelectric potential of river basins which are estimated to the amount of 142 billion KWh of electricity generation potential per year. Currently the level of use of all the potential water resources of Kyrgyzstan varies from 8 to $10 \%$, depending on the water availability of the year. The Naryn River basin has the highest level of development, reaching almost 50\% of production and capacity. The lower Naryn cascade of HPP consists of five hydroelectric stations: Toktogul (1200 MW), Kurpsai (800 MW), Tashkumyr (450 MW), Shamaldysai (240 MW) and Uchkurgan (180 MW). In addition it also 
includes very important facilities for CA irrigation (e.g. Toktogul reservoir). In the upper stream of Naryn River there is At-Bashy HPP (the installed capacity is $40 \mathrm{MW}$ ) while eight small hydroelectric plants with a total installed capacity 29.78 MW are located in the Chu River basin.

The hydraulic structures needed for the socio-economic development of the region to meet the needs of water, energy, flood control, have on the other hand a negative impact on the environment. The relationship between natural and social factors needs an integrated consideration of environmental issues. The construction and exploitation of the hydraulic structures could significantly affect the natural conditions, changes the ecosystem, the fauna and flora of the Naryn River. For the Naryn River with its high hydropower potential, the preservation of natural ecosystems and the biota of the river has a practical significance.

To detect the changes in the environment, predict and estimate the current situation and the future rational use of natural resources, the use of remotely sensed data and GIS (geoinformation systems) is required. The topical application of remote sensing techniques is the high information content of satellite images obtained at different temporal, spatial, spectral and radiometric resolutions. To represent an entire scene of the actual situation of the river valley is difficult. The cartographic materials used on paper nowadays are rapidly becoming outdated because the situation along the river may change several times during the year. The maps and cartographic materials are the most recognized sources of various data about the study area; they provide spatially defined information about the object. The efficiency of using remotely sensed and GIS data at the visualization and monitoring of the spatial - temporal changes and predicting the condition of the environment is confirmed by numerous successful applications.

With the use of satellite images, GIS and GPS (global positioning systems) data, the following geo-ecological problems may be solved: the collection and accumulation of data about the study area in the form of digital topographic maps and plans, the monitoring of the changes in the shape of reservoirs and water bodies shores, the updating of maps, the monitoring of the infrastructure, the monitoring of the changes in the environment, the prediction of floods on the territory and the development of flood prevention activities, the assessment of damages caused by natural disasters (e.g. floods) and the avoidance of accidents on the hydraulic structures which allow us to use water resources efficiently with a minimal damage to the environment. The geoinformation systems solving issues of multi-operational data from various sources are an effective means for the monitoring and estimation of emergency consequences (Shishkin et al., 2014). In parallel with the construction and exploitation of the hydraulic structures, one must consider that the territory of the Kyrgyz Republic is characterized by a mountainous terrain which continues to form at present time in the interaction of internal and external geological 
and geophysical processes. These processes are the cause for more than 20 types of natural hazards spread across the country. Their evolution and activation leads to emergency situations. Most often the occurrence of emergencies and disasters are due to natural processes, such as earthquakes (Kyrgyzstan territory belongs to the 8-9 point zone), landslides (about 7.5\% of the country is exposed to landslide processes, a danger to more than 600 settlements), mudflows and floods (approximately 95\% of all the settlements are exposed to potential danger from landslides and floods), avalanches (53\% of the country is exposed to the danger of avalanche).

\section{CONCLUSIONS}

The application of remote sensing data and GIS technologies using the appropriate methodologies and software packages can lead to the creation of digital maps used for the prediction of natural processes in the area of the hydraulic structures, which will help to protect the environment and optimize the engineering protection against emergencies. This would allow the provision of expeditious, reliable and full data about the location of potentially dangerous situations on the ground. The cartographic way of presenting information shows the nature and extent of the possible danger by using a spatial dimension of the emergency.

\section{REFERENCES}

1. Bulgakova, T. Ju., VovkI, G. (2014). The system-oriented approach to the analysis of spatial-temporal condition oftechnogenic systems. Interexpo Geo-Siberia. Number 1 / Volume 1.

2. Jasinski, V.A., Mironenkov A.P., Sarsembekov, T.T. (2011). A modern condition and prospects of development a small hydropower in the CIS countries, Industrial Overview, №14. Eurasian Development Bank. Almaty, p. 36.

3. Kasymova V.M., Arkhangelskaja A.V. (2011). Energy Security of Kyrgyzstan and the development of intergovernmental energy connections in the Eurasian Economic Community (Central Asia). Eurasian Economic Integration, №3 (12), p. 46.

4. Kasymova, V.M., Baetov, B. (2007). Energy of Kyrgyzstan: condition of the sector and prospects for intergovernmental cooperation, Central Asia and the Caucasus, № 6 (54), p. 116-127. 
5. Kiselevskaja, K.E. (2009). Application of the method of remote sensing for environmental monitoring, Mountain Informational and Analytical Bulletin. №1, p. 188-190.

6. Lipkin, V.I., Bogombaev, E.S. (2007). Micro hydro power plants: Manual usage, Bishkek, $30 \mathrm{p}$.

7. Mamatkanov, D.M., Bazhanova, L.V., Romanovsky, V.V. (2006). Water Resources of Kyrgyzstan at the present stage, Ilim, Bishkek, 276 p.

8. Rahimov, K.R. (2010). Kyrgyzstan Power lines, particular qualities, methods of calculation and management, KSTU named after I. Razzakov, IC "Teknik", Bishkek, 151 p.

9. Shakhramanyan, M.A. et al. (2003). Application of GIS technologies for flood hazard predicting. Civil Security Technologies. № 1-2, p. 62-68.

10. Shishkin, I.N., Skugarev, A.A. (2014). Application of geoinformation technologies for monitoring and evaluation the consequences of emergencies, Reports of TUSUR, № 2 (32), p. 276-280.

11. Program of complex monitoring and forecasting of natural hazard processes with the application of GIS and remote sensing in the 2015-2017 years, Erkin Too, May 5, 2015, № 40.

12. http://foraenergy.ru/

13. Transparency initiative of the fuel and energy complex of the Kyrgyz Republic. http://www.energoforum. $\mathrm{kg} /$ 